\title{
Expert system for risk prediction of cesarean section delivery with Dempster Shafer method
}

Cite as: AIP Conference Proceedings 2314, 040008 (2020); https://doi.org/10.1063/5.0035200 Published Online: 09 December 2020

Ismaiba, Riries Rulaningtyas, Katherine, and Ernawati

\section{ARTICLES YOU MAY BE INTERESTED IN}

Mechanical properties of Fe, Ni and Fe-Ni alloy: Strength and stiffness of materials using lammps molecular dynamics simulation

AIP Conference Proceedings 2314, 020008 (2020); https://doi.org/10.1063/5.0034046

Ball detection for KRSBI soccer robot using PeleeNet on omnidirectional camera AIP Conference Proceedings 2314, 040012 (2020); https://doi.org/10.1063/5.0036172

The detection of cadmium ion level in distilled water using $532 \mathrm{~nm}$ laser light based on the optical fiber spectrometry

AIP Conference Proceedings 2314, 030007 (2020); https://doi.org/10.1063/5.0034080

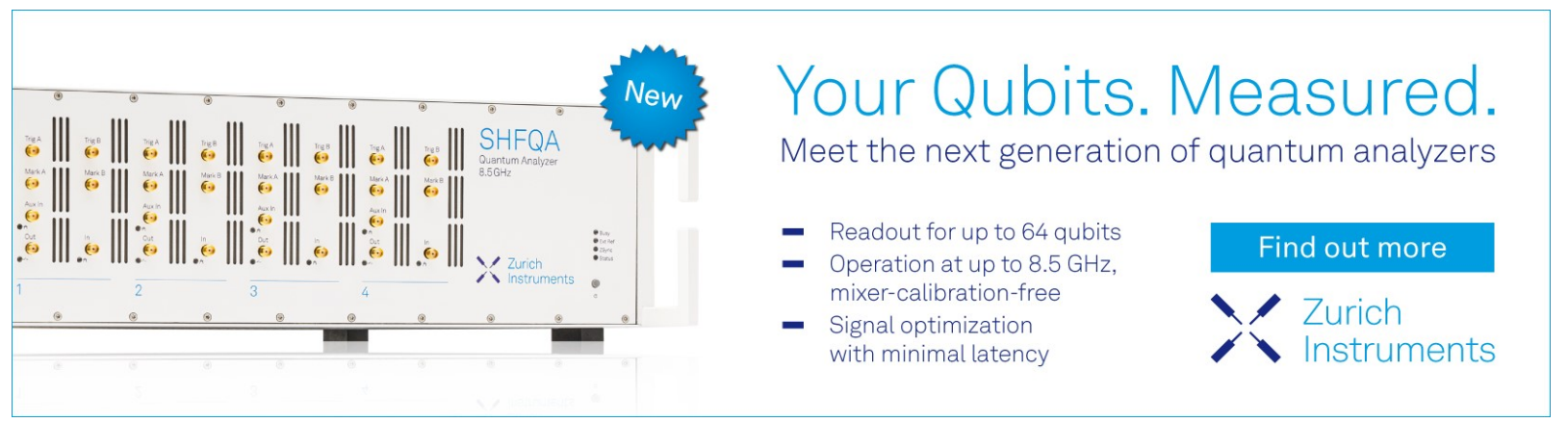




\title{
Expert System For Risk Prediction of Cesarean Section Delivery with Dempster Shafer Method
}

\author{
Ismaiba $^{1, \text { a) }}$ Riries Rulaningtyas $^{1, b)}$, Katherine ${ }^{1, c)}$, and Ernawati ${ }^{2, d)}$ \\ ${ }^{1}$ Biomedical Engineering Program Study, Faculty of Science and Technology, Universitas Airlangga Campus C, Zip \\ Code: 60115, Surabaya, East Java, Indonesia. \\ ${ }^{2}$ Fetomaternal Division of Obstetrics and Gynecology Department, Faculty of Medicine, Universitas Airlangga, \\ Campus A, Zip Code: 60131, Surabaya, East Java, Indonesia. \\ a)Corresponding author: ismaiba97@gmail.com \\ b)riries-r@fst.unair.ac.id, c)katherine-2016@fst.unair.ac.id, d)ernawati@fk.unair.ac.id
}

\begin{abstract}
The maternal mortality rate in Indonesia is related to the lack of knowledge of mothers regarding high-risk pregnancies, especially with cesarean delivery. In this case, the prediction system designed is done as an effort to increase the awareness of mothers or women who were preparing for high-risk pregnancies. In this article, an Android-based prediction application will be presented using an expert system with the Dempster Shafer method. This method is based on a mathematical theory which consists of a combination of belief function and plausible reasoning from the risk parameters of each labor class by representing the knowledge obtained from experts. This study uses 16 risk parameters as input based on Poejo Rochati's high-risk pregnancy card with 2 outputs, with risk or no risk of having cesarean delivery. The result obtained from this system is $85 \%$, concludes that the prediction system is able to predict the risk of cesarean delivery.
\end{abstract}

\section{INTRODUCTION}

Every delivery has risks for both mother and fetus, in the form of risks from morbidity to death. If the mother or fetus is in a condition that can cause labor complications, then to save both, the childbirth action is necessary, one of which is the cesarean section delivery (1). Risk factors that can cause cesarean delivery are factors originating from the fetus, biological maternal factors, and environmental factors. A pregnant woman who has knowledge of a high risk of pregnancy allows the mother to think and determine the right attitude, behave preventively, avoid or overcome these risks to maintain pregnancy and childbirth so that it can run safely and well (2).

As an effort to increase awareness of high-risk pregnancies and cesarean section deliveries in pregnant women is to predict the condition of labor by using an expert system - used to make decisions based on information by an expert. Using an expert system as an effort to make predictions can reduce inefficiencies in decision making directly.

Previous studies that used an expert system for cesarean delivery prediction is Naïve Bayes Classifier (3). This presented research is linked with the previous study using Naïve Bayes Classifier, with an accurate percentage of $80 \%$. Thus, the system developed with different methods is expected to increase the accuracy of the prediction system. Another reference for the method used in this research is premature delivery prediction (2) and preeclampsia prediction (4) that also used Dempster Shafer.

The prediction system presented in this article is using the Dempster Shafer method, a method that will gather information and knowledge from an expert in the form of a value called the belief function. The process of this method is the same as the standard used by an expert in making predictions, which is in the form of a list of questions regarding cesarean delivery.

The proceeding sections of the paper are organized as follows: Session 2 will explain the expert system in general and its implementation in making predictions. Session 3 will describe the system proposed to make

The 2nd International Conference on Physical Instrumentation and Advanced Materials 2019

AIP Conf. Proc. 2314, 040008-1-040008-4; https://doi.org/10.1063/5.0035200

Published by AIP Publishing. 978-0-7354-4056-2/\$30.00 
predictions. It will explain how the expert system process works with the Dempster Shafer method. Session 4 will show the application results from the prediction system. Session 5 will explain the conclusions of the study.

\section{EXPERT SYSTEMS}

The expert system is one of artificial intelligence as a computer science designed to model the problem-solving ability of an expert (5). The expert system is designed as a program that can do work as done by humans. The ability of expertise used is to be able to recognize and formulate problems, solve problems appropriately, and explain solutions (6). The structure of an expert system will be explained in Fig. 1 below.

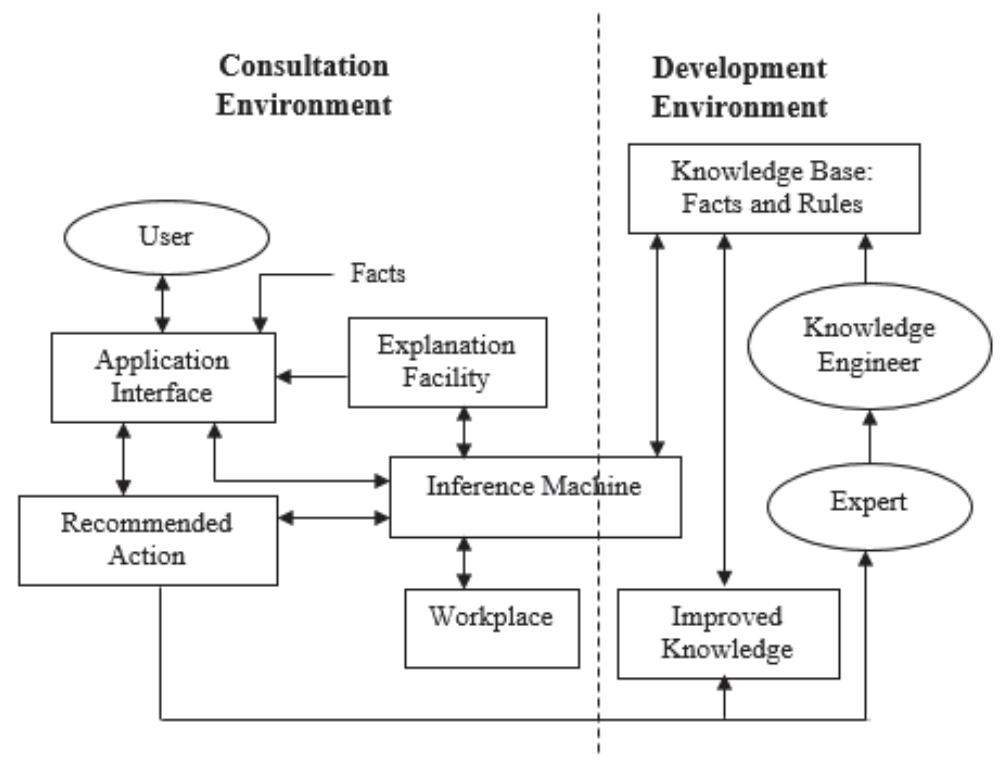

FIGURE 1. An Expert System Structure

The development environment is used as an expert system builder in terms of component development and knowledge base. Meanwhile, the consultation environment is used by someone who is not an expert to do a consultation. The two environments are interdependent with one another. In a development environment, the dependency between the knowledge base and the interference machine is very important. The knowledge base contains knowledge for formulating and solving problems. The knowledge base is composed of two basic elements namely facts and rules. An inference machine is a processor in an expert system that matches the conditions part of the rules stored in working memory.

\section{THE PREDICTION SYSTEM COMPUTATIONAL MODEL}

The prediction system presented in this article can be applied as information to pregnant women to increase awareness of high-risk pregnancies that will impact the delivery process that will be undertaken. The expert system method used is the Dempster Shafer method. Data will be processed by the Dempster Shafer method to determine the level of confidence of a conclusion based on the facts (cesarean delivery risk factors) that exist where there is a probability density value based on risk factors given by the user at the time the prediction is made. The type of inference machine used in this expert system is forward chaining. This method starts from a set of facts about risk factors and symptoms given by the user as input into the system, which is then calculated until the final goal in the form of a conclusion that is the prediction of the risk of cesarean delivery experienced.

Calculations performed in the Dempster Shafer method begin by determining the initial density which consists of the belief value and the value of plausibility. The belief value is the value of the trust held by each risk factor of cesarean section delivery. Experts, namely obstetricians and gynecologists (ob-gyn) is the ones who will give the belief value for each risk factor. Next, determine the new density value by creating a combination rule, obtained by using Equation 1 below. 


$$
m_{3}(Z)=\frac{\sum X \cap Y=Z m_{1}(X) \cdot m_{2}(Y)}{1-\sum X \cap Y=\emptyset m_{1}(X) \cdot m_{2}(Y)}
$$

With $\mathrm{m}_{3}(\mathrm{Z})$ is density function from evidence $(\mathrm{Z}), \mathrm{m}_{1}(\mathrm{X})$ is density function from evidence $(\mathrm{X})$, and $\mathrm{m}_{2}(\mathrm{Y})$ is density function from evidence $(Y)$. Prediction results are obtained by determining a large density value.

\section{APPLICATIONS AND RESULTS}

The prediction system design described in this article uses Android Studio as the user interface development software along with Genymotion software as the emulator for application test and evaluation. This system is called Labor Preparation or PREPER (Prediksi Persalinan) 2.0 in Bahasa as shown in Fig. 3. As many as 100 medical records were used as the test data, it consists of 50 normal delivery data and 50 cesarean delivery data. Those data were taken at Haji Hospital Surabaya (Rumah Sakit Haji Surabaya), Indonesia. This prediction system developed at the Biomedical Engineering Laboratory, Faculty of Science and Technology, Universitas Airlangga.

Overall, the prediction system is able to predict the risk of cesarean delivery, with an accurate percentage of $85 \%$. If the system can not provide a correct prediction on the data tested, it can be said that it is related to the current conditions of patients itself and also the ability of the system that is unable to predict the abnormal conditions.

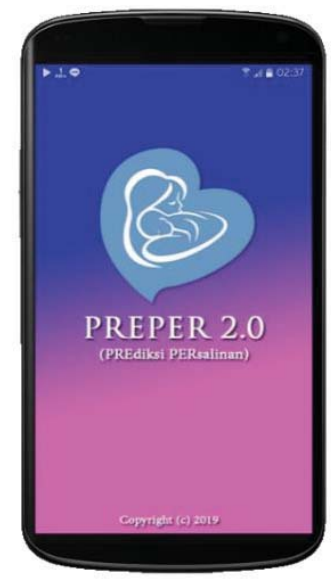

FIGURE 2. User Interface for the beginning of PREPER 2.0

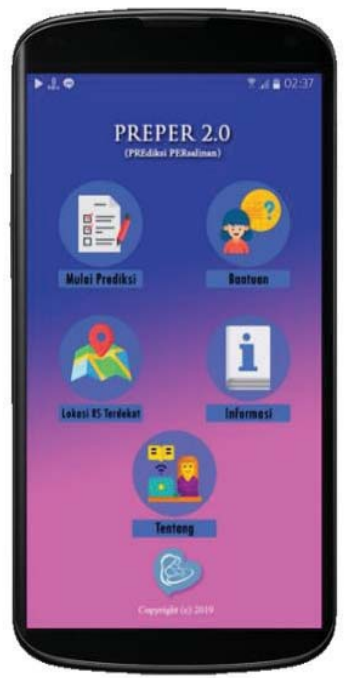

FIGURE 3. User Interface for the main menu of PREPER 2.0 
The prediction results displayed below show that the prediction system is able to provide fairly good results as an application used by people.

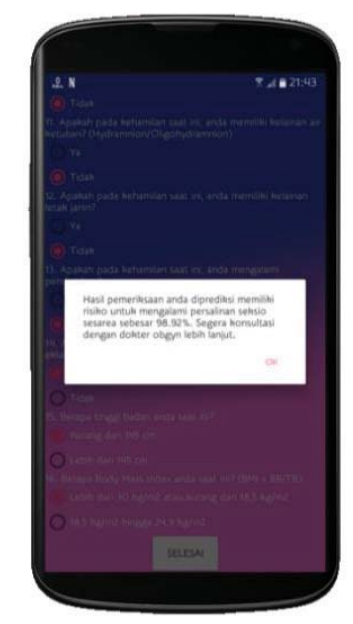

FIGURE 4. User Interface for the prediction results of PREPER 2.0

\section{CONCLUSION}

Artificial intelligence is one part of computer science, one of which is an expert system. The expert itself is an individual who has a superior understanding ability of a problem, for example, a doctor. The ability of expertise used is to be able to recognize and formulate problems, solve problems appropriately and explains solutions. The prediction system proposed in this article is based on the Dempster Shafer method which is represented by the belief value and plausibility value for each risk factor that is processed through a forward inference machine. The value of belief and the value of plausibility are given by experts in their field, in this case namely obstetricians and gynecologists. The results of this prediction system show an $85 \%$ percentage of accuracy which explains that the application is able to predict the risk of cesarean delivery properly.

Future development that can be done to this system is the additional information obtained to support the belief value of each risk factor with 2 or more experts in order to meet the knowledge base of the prediction system. Furthermore, this prediction system can be developed by storing data online so that it can be used periodically.

\section{ACKNOWLEDGMENTS}

The authors acknowledge Universitas Airlangga, Faculty of Science and Technology, Biomedical Engineering Laboratory and Haji Hospital Surabaya (RS Haji Surabaya).

\section{REFERENCES}

1. K. Yuli and S. H. S. Ariawan, "Faktor-Faktor yang Mempengaruhi Terhadap Persalinan Tindakan (Studi Kasus di RS dr Moewardi Surakarta)," Master thesis, Universitas Diponegoro, 2006.

2. A.H. Sindilas, "Perancangan Aplikasi Sistem Pakar Untuk Deteksi Risiko Persalinan Prematur dengan Metode Dempster Shafer," Undergraduate thesis, Universitas Airlangga, 2017.

3. E.N Iftitah, "Aplikasi Sistem Pakar untuk Prediksi Metode Persalinan dengan Naïve Bayes Classifier Berbasis Android," Undergraduate thesis, Universitas Airlangga, 2018.

4. N. W. Achmadi, "Perancangan Aplikasi Sistem Pakar untuk Deteksi Resiko Preeklampsia Dengan Metode Dempster Shafer berbasis Android," Undergraduate thesis, Universitas Airlangga, 2018.

5. J. Durkin, Expert System: Design and Development (Prentice Hall Int. Inc, New Jersey, 1994)

6. D. Lestari. Definisi Sistem Pakar. (Arsip Teknik Informatika UMMI, 2012) 